\title{
Inhibitory Effects of High Concentrations of Estrogen, Progesterone and Tamoxifen on Proliferation of HeLa in Culture
}

\section{Gyesik Min*}

\section{Department of Pharmaceutical Engineering, Gyeangnam National University of Science \& Techndogy, Jinju 660-758, Korea}

Received October 31, 2011 /Revised November 10, 2011 / Accepted November 11, 2011

\begin{abstract}
This study examined the effects of estrogen, progesterone and tamoxifen at different concentrations and treatment periods on proliferation of a human cervical carcinoma cell line, HeLa, in culture, based on MTT assay. Estrogen did not have an effect on the cellular proliferation in concentrations up to $1 \mathrm{\mu g} / \mathrm{ml}$ for treatment periods of between 2.5 and 6 days, but significantly inhibited proliferation at a higher concentration of $10 \mathrm{\mu g} / \mathrm{ml}$ in a progressive manner with increasing treatment periods. Also, treatment of HeLa with more than $10 \mathrm{\mu g} / \mathrm{ml}$ of progesterone for 2.5 days significantly inhibited proliferation and caused a concentration-dependent inhibition with 4 days of treatment. However, longer treatment with progesterone for 6 days abolished the concentration-dependent inhibitory effect on cellular proliferation observed with the 4-day treatment period. Furthermore, tamoxifen required a higher concentration $(100 \mathrm{\mu g} / \mathrm{ml})$ than estrogen to bring about the inhibitory effect on the HeLa proliferation. These results suggest that high concentrations of estrogen, progesterone and tamoxifen may suppress proliferation of HeLa, and both the concentration and the treatment period may also influence their inhibitory effects on cellular proliferation.
\end{abstract}

Key words : Estrogen, progesterone, proliferation, tamoxifen, HeLa

\section{서 론}

에스트로겐은 콜레스테롤로부터 합성되는 성 스테로이드 호르몬으로서 주로 난소에서 합성, 분비되지만 태반, 지방조 직 및 부신에서도 생성된다. 에스트로겐은 핵수용체인 $\mathrm{ERa}$ 와 $\mathrm{ER} \beta$ 그리고 막 에스트로겐 수용체를 통하여 난포의 발달과 성숙, 유선의 분화와 발달, 뇌, 심혈관계, 그리고 자궁 및 자궁 경부와 같은 여성의 생식기도의 발달에 중요한 기능을 한다 [7]. 생리적으로 활성을 갖는 에스트로겐 중 하나인 $17 \beta$ -estradiol (E2)은 복잡한 신호전달기전에 의해 다양한 세포 내 효과를 발휘하는 것으로 여겨진다. 에스트로겐은 세포질에 위 치한 핵수용체와 결합하여 동종이합체 또는 이질이합체를 유 도한다. 에스트로겐과 결합된 핵수용체는 핵으로 전위되어 에 스트로겐 반응염기서열과 결합하거나 enhancer 부위에 결합 된 전사조절인자와 상호작용하여 표적유전자의 발현을 조절 한다. 에스트로겐은 또한 $\mathrm{G}$ 단백질 연계 수용체의 하나에 해 당하는 막 수용체에 결합하여 단백질 인산화효소를 포함하는 신속한 신호전달경로를 통하여 표적세포에 따라 다양한 생리 적 작용을 나타낸다[6].

자궁경부의 상피세포는 주로 $\mathrm{ERa}$ 를 발현하여 생리주기 동 안 증가하는 에스트로겐의 혈중농도에 의해 분화와 증식을 유도하는데, 때로는 점진적으로 암을 초래하기도 한다. 자궁

*Corresponding author

Tel : +82-55-751-3396, Fax : +82-55-751-3399

E-mail : g-min@gntech.ac.kr
경부암은 여성에서 두 번째로 가장 흔한 암으로서 연간 20만 명 이상의 사망을 초래한다[6]. 이러한 높은 사망률은 효율적 인 치료법의 부재와 약물치료에 대한 반응결핍에 기인하는 것으로 추정된다. 자궁경부암은 주로 고위험성 human papillomavirus (HPVs)에 감염된 뒤 서서히 발달하여 10여 년에 걸쳐 확립되며 지속적인 감염은 심각한 상피 내 종양을 초래 한다. 여러 연구에 의하면, 에스트로겐이 자궁경부 암의 발생 에 중요한 역할을 하는 것으로 알려져 있다. 예를 들어, HPV 형질전환 생쥐는 자연발생적으로 자궁경부암을 발생하지 않 는 반면, 외인성 17ß-estradiol을 처리하였을 경우 암의 발생을 유도하였으며[2,21,25], 에스트로겐의 제거는 자궁경부암의 진 행을 감소시킴으로써 에스트로겐이 자궁경부의 암 형성에 관 여하는 증거를 제공하였다[4].

그러나 최근의 보고에 의하면 $\mathrm{E} 2$ 가 여러 유형의 세포에서 세포사멸을 현저히 증가함으로써 세포성장을 억제할 수 있음 을 입증하였다[28]. 특히, 임상적 및 실험적 증거에 의하면, E2 가 전립선과 대장 세포의 증식을 억제하는 것으로 보고되고 있다 $[3,9,12,13]$. ER $\beta$ 가 이러한 E2 유도에 의한 세포증식의 억 제에 관여하는 것으로 여겨진다. $\mathrm{ER} \beta$ 의 발현이 유선과 전립선 의 암 형성과정에서 점차적으로 감소하였으며 $[9,24]$, 대장조직 에서 주로 발현되는 에스트로겐 수용체로 사람의 악성 대장암 에서 발현이 억제되었다[13,31]. 또한 ERß가 $\mathrm{ERa}$ 에 의해 매개 된 세포증식 관련 전사활성을 억제하는 것으로 보아[11,12,19], $\mathrm{ERB}$ 는 E2 신호전달에 대한 조절인자로 작용할 수 있음이 제 안되었다[12]. 뿐만 아니라, 에스트로겐은 유방암 및 전립선 
암세포 등에서도 세포사멸을 현저히 증가시켜 암세포의 증식 을 억제하는 것으로 보고하고 있다[22,27]. 에스트로겐에 의한 이러한 결과는 세포증식에 대한 에스트로겐의 또 다른 조절작 용을 제시한다. 또한 자궁경부 암세포 유래 Hela 세포주에서 는 $\mathrm{ERa}$ 유전자를 주입한 경우에 한하여 에스트로겐이 MAP kinase를 활성화하여 세포사멸을 유도하는 것으로 보고된 예 가 있지만[33] 내인성 에스트로겐 수용체에 의한 에스트로겐 의 세포증식 억제효과에 대한 연구는 아직 보고되어 있지 않 다. 또한 선택적 에스트로겐 수용체 조절인자들(SERMs) 중의 하나로 알려진 타목시펜은 조직-특이적으로 작용하여 유선조 직에서는 세포의 증식을 억제하지만 자궁내막에서는 세포증 식을 촉진하는 이중적 역할을 하는 것으로 알려져 있다[16]. 따라서, 에스트로겐과 타목시펜의 다양하고 때로는 상반적인 생리적 작용의 규명을 위해서는 표적조직세포와 세포의 특이 적인 생리적 상태에 따라 독립적으로 연구되어야 할 필요가 있을 것으로 사료된다.

프로게스테론(P4)은 포유동물에서 임신유지와 자궁내막의 증식에 관여하는 중요한 여성 스테로이드 호르몬이다. 또한 프로게스테론은 난소조직 상피암 발생에 대한 방어적인 역할 을 하는 것으로 보고되고 있다[23]. 다산 또는 높은 프로게스테 론 농도와 연관이 있는 쌍둥이를 출산한 경험이 있는 여성에 있어서 난소 암 발병률이 감소한다는 보고는[1,14] 임신수준의 높은 프로게스테론에 대한 증가된 노출이 난소 암으로부터 보호함을 제시한다. 이러한 보고와 일치하게, 다수의 연구에 서 P4 또는 다른 프로게스틴이 정상 및 악성 사람 난소 표면상 피세포의 성장을 억제하고 세포사멸을 유도하는 것으로 나타 났다 $[5,10,23,29,30]$. 그러나 자궁경부 암세포의 증식에 대한 프 로게스테론의 영향에 관한 연구는 아직 보고되어 있지 않다. 따라서 본 연구에서는 다양한 고농도와 처리기간에 따라 에스트로겐, 프로게스테론 그리고 타목시펜이 자궁경부암세 포주인 $\mathrm{HeLa}$ 의 증식에 미치는 영향을 조사하고자 하였다.

\section{재료 및 방법}

HeLa 세포주는 American Type Culture Collection (ATCC HTB-22; Rockville, MD)로부터 구입하였으며, 30 40 회 계대 배양을 통하여 실험에 사용되었다. 배양을 위한 Dulbeco's Modified Eagle's Medium (DMEM) 및 태아송아지 혈청은 GIBCO Invitrogen (Grand Island, NY, USA)으로부터, 그리고 세포배양 플레이트는 Nunc A/S (Roskilde, Denmark)로부터 구입하였다. 17ß-estradiol, progesterone (P4), 그리고 tamoxifen은 Sigma (St. Louis, MO, USA)로부터 구입하였다.

\section{Cell culture}

사람 자궁경부암세포주인 $\mathrm{HeLa}$ 세포는 $5 \%$ 태아송아지 혈 청, $100 \mathrm{U}$ 의 penicillin 그리고 $100 \mathrm{mg} / \mathrm{ml}$ 의 streptomycin으로
첨가된 DMEM 내에서 배양을 유지하였다. 배양된 세포는 phosphate buffered saline (PBS)에 용해된 0.05\% trypsin 및 $2 \mathrm{mM}$ EDTA로 $37^{\circ} \mathrm{C}, 5$ 분간 처리하여 배양된 $10 \mathrm{~cm}$ 플레이트 로부터 분리하고, Trypan Blue 염색을 통한 Hemacytometer 로 세포수를 counting 한 다음, 각 호르몬 농도 별 처리 군에 따라 96-well 또는 48-well plate에 3,000 4,000 cell/well을 균 등히 분주하였다. 분주된 $\mathrm{HeLa}$ 세포는 각 농도별 호르몬 처리 전 $12 \mathrm{hr}$ 동안 $5 \% \mathrm{CO}, 37^{\circ} \mathrm{C}$ 에서 배양하였다.

\section{Cell Proliferation assay (MTT assay)}

다양한 농도의 $17 \beta$-estradiol (E2; 0, 10, 100, 1,000, 10,000 $\mathrm{ng} / \mathrm{ml}$ 의 $\mathrm{EtOH}$ ), progesterone (P4; 0, 100, 1,000, 10,000, $100,000 \mathrm{ng} / \mathrm{ml}$ 의 DMSO) 그리고 tamoxifen $(0,1,000,5,000$, $10,000,100,000 \mathrm{ng} / \mathrm{ml}$ 의 EtOH)을 96-well 또는 48-well plate 에 균등히 분주된 $\mathrm{HeLa}$ 배양세포에 첨가한 다음, 에스트로겐 과 프로게스테론은 2.5 일, 4 일 그리고 6 일 동안 처리하였으며, 타목시펜은 6일 동안 처리하였다. 각 호르몬과 배양액은 매 48시간 마다 교체하였다. 각 처리 별 세포의 증식은 시약공급 자의 프로토콜(CellTiter 96 Aqueous One Solution)에 따라 colorimetric MTT (Promega, Madison, WI) 세포분석법에 의 해 분석되었다. 간단히 말하면, 100 150 lㅣㅇㅢ 배양액 내 세포를 함유하는 plate의 각 well에 $2 \mu \mathrm{l}$ 의 MTS 반응용액을 첨가하여 $37^{\circ} \mathrm{C}, \mathrm{CO}_{2}$ incubator에서 약 40 분간 반응시킨 후 $490 \mathrm{~nm}$ 에서 흡광도를 측정하였다. 이러한 실험은 각각 6회 반복하였으며, 값은 흡광도 단위/well로 표시하였다.

\section{Statistical analysis}

실험결과는 평균 $\pm \mathrm{SE}$ 로 표시되었으며, 처리군 사이의 통계 적 유의성은 Student's t-test에 의해 결정되었다. $p<0.05$ 의 값 은 통계적으로 유의성이 있음을 의미한다.

\section{결 과}

\section{에스트로겐 및 프로게스테론의 2.5일 처리효과}

배양된 HeLa 세포를 에스트로겐으로 2.5일 처리하였을 경 우, 10 1,000 ng/ml의 농도에서는 대조군 ethanol처리와 비교 하여 세포성장에 차이를 보이지 않았지만, $10 \mu \mathrm{g} / \mathrm{ml}$ 고농도 의 에스트로겐 처리는 대조군 세포증식의 $50 \%$ 를 억제하였다 (Fig. 1A). 이와 유사하게, 프로게스테론에 의한 2.5일 처리 또 한 100 1,000 ng/ml 농도범위에서 DMSO 대조군에 비해 $\mathrm{HeLa}$ 세포 증식의 차이를 보이지 않았으나, $10 \mathrm{\mu g} / \mathrm{ml}$ 과 100 $\mu \mathrm{g} / \mathrm{ml}$ 의 고농도에서 각각 $50 \%$ 및 $70 \%$ 의 증식억제효과를 나 타내었다(Fig. 1B).

에스트로겐 및 프로게스테론의 4일 처리효과

에스트로겐에 의한 2.5일 처리에서와 마찬가지로, 10 1,000 
(A)

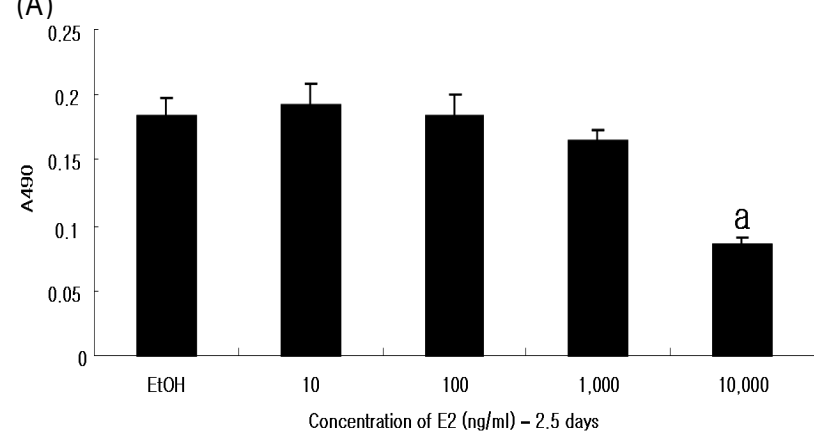

(B)

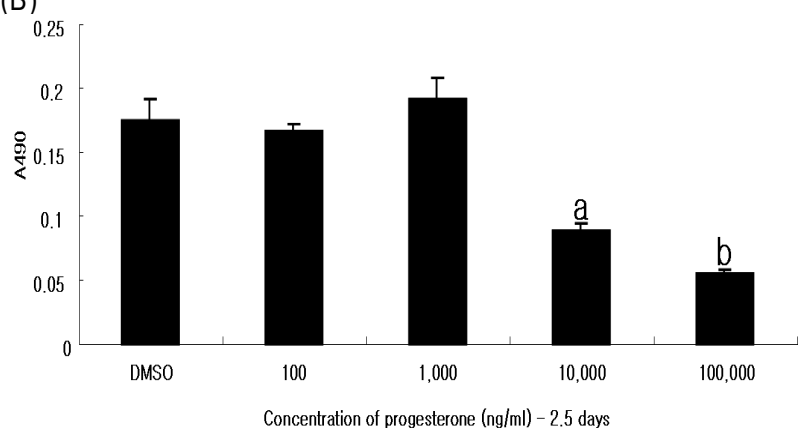

Fig. 1. Inhibitory effects of estrogen and progesterone on proliferation of HeLa as measured by MTT cell proliferation assay. HeLa cells were incubated for 2.5 days with different concentrations of 17-beta estradiol (A) or progesterone (B) as indicated. Values are expressed as means from six independent experiments. Error bars indicate standard errors. a. $p<0.05$, b. $p<0.01$ as compared to control.

$\mathrm{ng} / \mathrm{ml}$ 의 에스트로겐 농도에서 4 일 처리시 대조군 ethanol 처 리와 비교하여 $\mathrm{HeLa}$ 세포주의 성장에 차이를 나타내지 않았 으며, $10 \mu \mathrm{g} / \mathrm{ml}$ 의 고농도 에스트로겐에서는 대조군 세포증식 의 $60 \%$ 억제효과를 보였다(Fig. $2 \mathrm{~A}$ ). 프로게스테론에 의한 4 일 처리는 $100 \mathrm{ng} / \mathrm{ml} 100 \mu \mathrm{g} / \mathrm{ml}$ 농도범위에서 농도-의존성 세 포증식 억제효과를 보였다(Fig. 2B).

\section{에스트로겐 및 프로게스테론의 6 일 처리효과}

에스트로겐에 의한 6일 처리 또한 $10 ~ 1,000 \mathrm{ng} / \mathrm{ml}$ 의 농도 에서는 대조군 처리와 비교하여 $\mathrm{HeLa}$ 세포주의 증식에 차이 를 보이지 않았으나, $10 \mu \mathrm{g} / \mathrm{ml}$ 의 고농도 에스트로겐에서는 대조군 세포증식의 $70 \%$ 억제효과를 나타냈다(Fig. $3 \mathrm{~A}$ ). 흥미 롭게도 6 일 동안의 프로게스테론 처리에서는, 4 일 처리기간 동안 나타난 농도-의존성 $\mathrm{HeLa}$ 세포주의 증식억제효과가 사 라졌을 뿐만 아니라, $10 \mu \mathrm{g} / \mathrm{ml}$ 및 $100 \mu \mathrm{g} / \mathrm{ml}$ 의 고농도 처리 에서도 2.5 일 및 4 일 처리기간과 달리 대조군 대비 각각 $55 \%$ 와 $40 \%$ 의 감소된 억제효과를 보였다(Fig. 3B).

\section{타목시펜에 의한 HeLa 증식 억제효과}

타목시펜에 의한 6일 처리는 $1 \sim 10 \mu \mathrm{M}$ 범위의 농도에서는 대조군 처리와 비교하여 $\mathrm{HeLa}$ 세포주의 증식에 영향을 미치
(A)

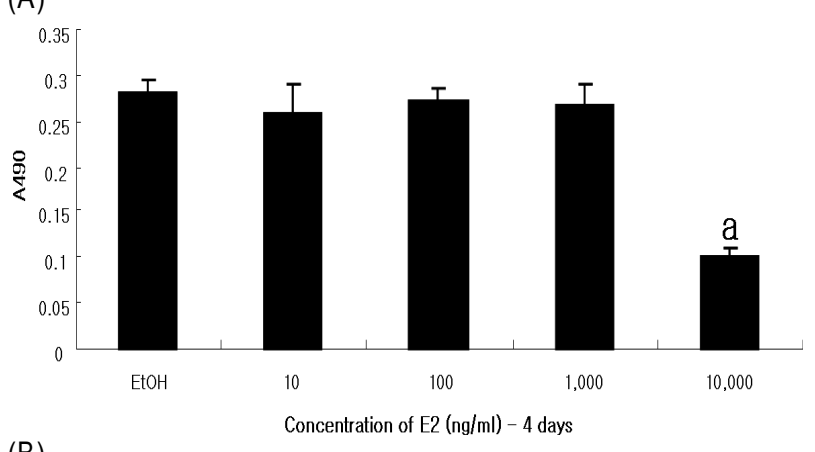

(B)

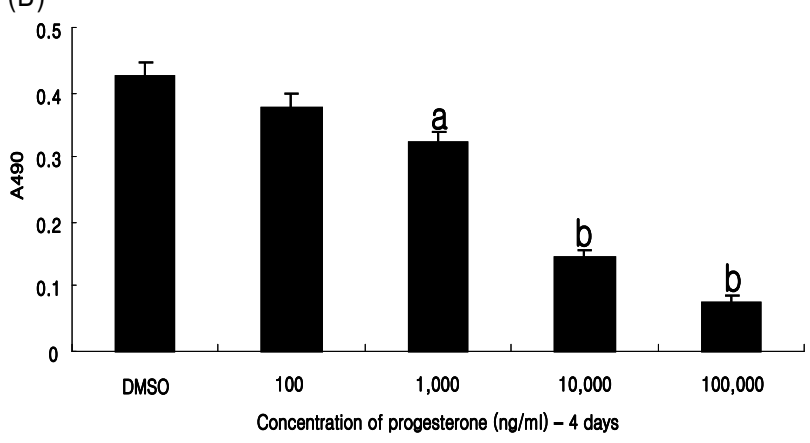

Fig. 2. Inhibitory effects of estrogen and progesterone on proliferation of HeLa as measured by MTT cell proliferation assay. HeLa cells were incubated for 4 days with different concentrations of 17-beta estradiol (A) or progesterone (B) as indicated. Values are expressed as means from six independent experiments. Error bars indicate standard errors. a. $p<0.05$, b. $p<0.01$ as compared to control.

지 않았으나, $100 \mu \mathrm{g} / \mathrm{ml}$ 의 고농도에서는 $70 \%$ 이상 감소하였 다(Fig. 4). 이는 에스트로겐에 의한 유사한 증식억제효과 (70\%)를 달성하기 위하여 에스트로겐 농도보다 10 배 더 높은 타목세펜의 농도를 필요로 함을 나타낸다.

\section{고 찰}

이 연구의 결과는 에스트로겐이 정상적인 생리조건에서 작 용하는 세포사멸 억제효과 이외에도, 세포사멸 작용을 통해 유방암 세포를 포함한 전립선 암세포, 신경세포, 골아세포 및 에스트로겐 수용체 형질전환 세포 등의 세포성장 감소를 초래 한다는 이전의 연구보고와[28] 일치한다. 특히 생리적 수준의 에스트로겐도 장기간 에스트로겐이 결핍되었거나 오랫동안 항-에스트로겐에 노출된 유방암 세포에서 세포사멸을 유도할 뿐만 아니라[15,27], 전이형태의 유방암을 않는 갱년기 여성의 치료를 위해 고 용량의 에스트로겐이 사용된 이전의 예는[15] 에스트로겐 매개에 의한 암세포 사멸효과를 보여주는 또 다른 범주의 에스트로겐 작용에 대한 증거로 제공된다. 이전의 보 고에서와 같이[20], 낮은 농도의 에스트로겐 $(10 ~ 1,000 \mathrm{ng} / \mathrm{ml})$ 은 조사된 모든 다른 기간 동안(2.5 6일) 배양된 $\mathrm{HeLa}$ 세포의 성장에 영향을 미치지 않았다. 그러나 $10 \mu \mathrm{g} / \mathrm{ml}$ 의 고농도 E2 

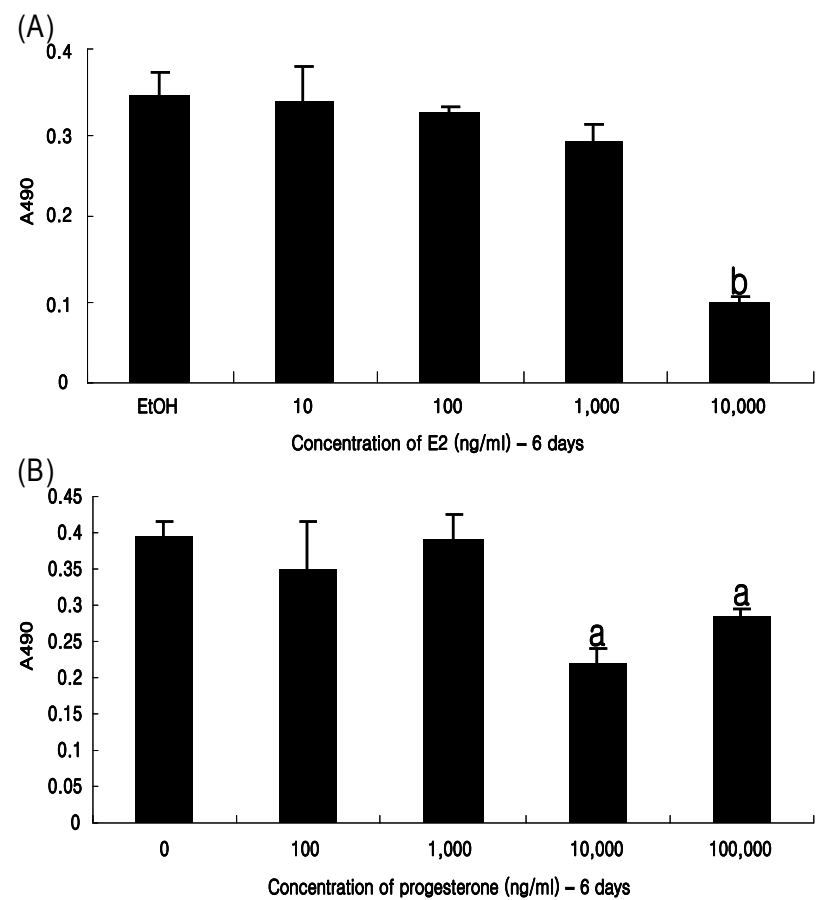

Fig. 3. Inhibitory effects of estrogen and progesterone on proliferation of HeLa as measured by MTT cell proliferation assay. HeLa cells were incubated for 6 days with different concentrations of 17-beta estradiol (A) or progesterone (B) as indicated. Values are expressed as means from six independent experiments. Error bars indicate standard errors. a. $p<0.05$, b. $p<0.01$ as compared to control.

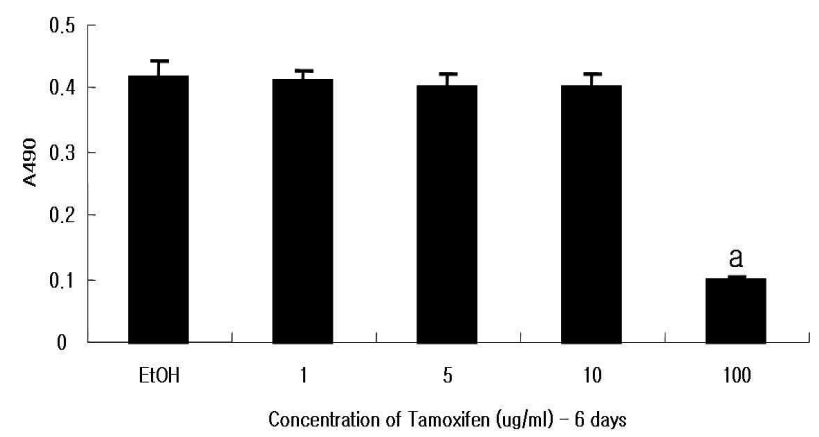

Fig. 4. Inhibitory effects of tamoxifen on proliferation of HeLa as measured by MTT cell proliferation assay. HeLa cells were incubated for 6 days with different concentrations of tamoxifen as indicated. Values are expressed as means from six independent experiments. Error bars indicate standard errors. a. $p<0.01$ as compared to control.

의 처리는 모든 처리기간에서 세포증식을 억제하였을 뿐만 아니라, 처리기간이 길어질수록 억제효과가 증가함을 보였다 (2.5일, 4일 및 6일 처리기간에 대하여 각각 평균 $50 \%, 60 \%$ 및 $70 \%$ 의 억제효과를 나타냄, Fig. $1 \mathrm{~A}, 2 \mathrm{~A}, 3 \mathrm{~A}$ 참조). 이러한 결과는 ERa 유전자를 주입한 Hela 세포주에서 에스트로겐이 MAP kinase를 활성화하여 세포사멸을 유도한다는 이전의 보

고[33]와 일치할 뿐만 아니라, 고 농도의 에스트로겐이 내인성 에스트로겐 수용체의 매개에 의한 자궁경부 암세포의 증식을 억제할 수 있음을 제시하는 in vitro 증거를 제공한다.

에스트로겐이 암세포의 성장을 억제하는 자세한 기전은 아 직 잘 알려져 있지 않지만, 특정한 조건 또는 선택적인 유형의 조직과 암세포에서 세포사멸 촉진효과를 나타내는 증거들이 보고되어 왔다. 먼저, 다년간의 갱년기를 경험한 여성 또는 tamoxifen에 의한 약물 치료 이후 에스트로겐에 의한 유방암 세포 성장의 억제효과는 낮은 혈중 에스트로겐 농도에 대한 암세포의 적응으로 인하여 에스트로겐의 세포사멸 촉진효과 에 대한 민감성 증대에 기인한 것으로 보고되었다[26,27,32]. 또한 ERa로 형질전환된 생쥐배아 섬유아세포와 Raf-1으로 형 질진환된 MCF-7 세포에서 에스트로겐이 세포사멸을 유도하 였으며[8], $\mathrm{ERa}$ 가 아닌 $\mathrm{ER} \beta$ 를 함유한 신경세포는 에스트로겐 에 반응하여 세포사멸을 초래하였다[18].

이 연구의 결과는 또한 고농도의 프로게스테론이 자궁경부 암세포의 증식을 억제할 수 있으며 처리기간에 따라 세포증식 에 대한 억제효율이 달라질 수 있음을 시사한다. 비록 프로게 스테론이 어떻게 HeLa 세포에 대하여 증식억제 작용을 나타 내는지에 대한 기전은 아직 알려져 있지 않으나, 난소와 자궁 내막에 작용하는 프로게스테론에 대한 이전의 연구결과는 프 로게스테론에 의한 세포사멸 촉진기능을 제시한다. 프로게스 테론은 난소 암과 자궁내막 암세포에서 활성산소의 발생을 억제하고, $\mathrm{P} 53$ 와 같은 세포사멸촉진인자의 발현을 증가시키 는 반면 BCL-2 유전자와 같은 세포사멸억제인자의 발현을 감 소시킴으로써 이들 암세포의 세포사멸을 일으키는 것으로 보 고되었다[17]. 이와 관련하여 정상 또는 악성종양 난소 표면상 피의 세포사멸 또한 프로게스테론에 의해 유도되는 transforming growth factor- $\beta$ (TGF- $\beta$ )의 차별적 발현조절 및 caspase-매개 Fas/FasL 신호전달경로의 활성화와 밀접히 연관된 다는 보고 $[23,30]$ 는 난소 암 발생 억제를 위한 프로게스테론의 방어적 역할에 대한 가능한 분자적 기전들을 제시한다.

에스트로겐보다 더 높은 농도의 타목시펜에 의한 $\mathrm{HeLa}$ 세 포주의 성장 억제효과는 조직특이적으로 다르게 작용하는 것 으로 알려진 타목시펜의 이중적 기능에 비추어 볼 때, $\mathrm{HeLa}$ 세포주에서는 고 농도 에스트로겐의 세포증식 억제효과와 유 사한 약한 에스트로겐 작용제(agonist)로 기능함을 제시한다. 타목시펜은 유방암 치료제로서 지난 30 여년 동안 임상에서 사용되어 왔지만, 조직에 따라서 순수한 E2 길항제로 작용하 지 않고 에스트로겐 agonist로 작용함이 알려져 왔다. 예를 들 어, 에스트로겐의 사용은 자궁암과 유방암의 발생위험을 높이 며, 타목시펜 또한 자궁성장 촉진제로 작용하여 자궁암의 발 생증가와 관련된다. 이러한 타목시펜의 작용에 관한 자세한 기전은 아직 잘 알려져 있지 않지만, 에스트로겐 수용체의 분 자생물학적 기전에 대한 최근의 연구결과들은 타목시펜과 같 은 SERM (Selective Estrogen Receptor Modulator)들이 조직 
특이적 작용을 일으키는 기전을 이해할 수 있는 다양한 증거 를 제공하였다[16]. 즉, 수용체의 기능을 조절할 수 있는 다수 의 보조활성인자 및 보조억제인자와 두 가지 유형의 에스트로 겐 수용체의 존재는 SERM이 다양한 조직-특이적 반응을 유도 할 수 있는 잠재적 복잡성을 예시하며, 각 SERM의 결합으로 다르게 영향을 미치는 $\mathrm{ER}$ 리간드 결합부위의 다양한 구조적 변형은 이러한 부류의 리간드에 의한 다양한 생물학적 반응에 대한 정보를 제공한다[16]. 본 연구에서 나타난 고 농도의 에스 트로겐, 프로게스테론 및 타목시펜 매개 HeLa 세포의 증식억 제에 대한 구체적인 신호전달 기전은 향후 규명되어야 할 것 이다.

결론적으로, 본 연구의 결과는 고농도의 에스트로겐, 프로 게스테론 그리고 타목시펜이 $\mathrm{HeLa}$ 세포의 증식을 억제할 뿐 만 아니라, 농도 및 처리기간 또한 세포증식에 대한 억제효과 에 영향을 미칠 수 있음을 제시한다.

\section{감사의 글}

이 논문은 2010년도 경남과학기술대학교 기성회 연구비 지 원에 의하여 연구되었으며 이에 감사 드립니다.

\section{References}

1. Adami, H. O., C. C. Hsieh, M. Lambe, D. Trichopoulos, D. Leon, I. Persson, A. Ekbom, and P. O. Janson. 1994. Parity, age at first childbirth, and risk of ovarian cancer. Lancet 344 , 1250-1254.

2. Arbeit, J. M., P. M. Howley, and D. Hanahan. 1996. Chronic estrogen-induced cervical and vaginal squamous carcinogenesis in human papillomavirus type 16 transgenic mice. Proc. Natl. Acad Sci. 93, 2930-2935.

3. Bardin, A., N. Boulle, G. Lazennec, F. Vignon, and P. Pojol. 2004. Loss of ER $\beta$ expression as a common step in estrogen -dependent tumor progression. Endocrine Related Cancer 11, 537-551.

4. Brake, T., and P. F. Lambert. 2005. Estrogen contributes to the onset, persistence, and malignant progression of cervical cancer in a human papillomavirus-transgenic mouse model. Proc. Natl. Acad Sci. 102, 2490-2495.

5. Bu, S. Z., D. L.Yin, X. H. Ren, L. Z. Jiang, Z. J. Wu, Q. R. Gao, and G. Pei. 1997. Progesterone induces apoptosis and up-regulation of p53 expression in human ovarian carcinoma cell lines. Cancer 79, 1944-1950.

6. Chung, S. H., S. Franceschi, and P. F. Lambert1. 2010. Estrogen and ERa: Culprits in Cervical Cancer? Trends Endocrinol. Metab. 21, 504-511.

7. Deroo, B. J. and K. S. Korach. 2006. Estrogen receptors and human disease. J. Clin. Invest. 116, 561-570.

8. EL-Ashry, D., D. A. Miller, S. Kharbanda, M. E. Lippman, and F. G. Kern. 1997. Constitutive Raf-1 kinase activity in breast cancer cells induces both estrogen-independent growth and apoptosis. Oncogene 15, 423-435.

9. Horvath, L. G., S. M. Henshall, C. S. Lee, D. R. Head, D. I. Quinn, S. Makela, W. Delprado, D. Golovsky, P. C. Brenner, G. O'Neill, R. Kooner, P. D. Stricker, J. J. Grygiel, J. A. Gustaffson, and R. L. Sutherland. 2001. Frequent loss of estrogen receptor- $\beta$ receptor expression in prostate cancer. Cancer Res. 61, 5331-5335.

10. Hu, Z. and X. Deng. 2000. The effect of progesterone on proliferation and apoptosis in ovarian cancer cell. Zhonghua Fu Chan Ke Za Zhi. 35, 423-426.

11. Imamov, O., G. J. Shim, M. Waner, and J. A. Gustafsson. 2005. Estrogen receptor beta in health and disease. Biol. Reprod 73, 866-871.

12. Koehler, K. F., L. A. Helguero, L. A. Haldosen, M. Warner, and J. A. Gustafsson. 2005. Refelections on the discovery and significance of estrogen receptor $\beta$. Endocrine Reviews 26, 465-478.

13. Konstantinopoulos, P. A., A. Kominea, G. Vandoros, G. P. Sykiotis, P. Andricopoulos, I. Varakis, G. SotiropoulosBonikou, and A. G. Papavassiliou. 2003. Oestrogen receptor beta $(E R \beta)$ is abundantly expressed in normal colonic muco$\mathrm{sa}$, but declines in colon adenocarcinoma paralleling the tumor's dedifferentiation. European J. Cancer 39, 1251-1258.

14. Lambe, M., J. Wuu, M. A. Rossing, and C. C. Hsieh. 1999. Twinning and maternal risk of ovarian cancer. Lancet 353, 1941.

15. Lewis-Wambi, J. S. and V. C. Jordan. 2009. Estrogen regulation of apoptosis: how can one hormone stimulate and inhibit? Breast Cancer Res. 11, 206.

16. Lonard, D. M. and Smith C. L. 2002. Molecular perspectives on selective estrogen receptor modulators (SERMs); progress in understanding their tissue-specific agonist and antagonist actions. Steroids 67, 15-24.

17. Nguyen, H. and V. Syed. 2011. Progesterone inhibits growth and induces apoptosis in cancer cells through modulation of reactive oxygen species. Gynecol. Endocrinol. 27, 830-836.

18. Nilsen, J., G. Mor, and F. Nafrolin. 2000. Estrogen-regulated developmental neuronal apoptosis is determined by estrogen receptor subtype and the Fas/Fas ligand system. J. Neurobiol. 43, 64-78.

19. Petterson, K., K. Grandien, G. G. Kuiper, and J. A. Gustafsson. 1997. Mouse estrogen receptor $\beta$ forms estrogen response element-binding heterodimers with estrogen receptor a. Mol. Endocrinol. 11, 1486-1496.

20. Rho, Y. S. and G. Min. 2005. Relaxin does not influence the growth of human cervical adenocarcinoma (HeLa) cells in culture. Ann. N. Y. Acad Sci. 1041, 470-480.

21. Riley, R. R, S. Duensing, T. Brake, K. Münger, P. F. Lambert, and J. M. Arbeit. Dissection of human papillomavirus E6 and E7 function in transgenic mouse models of cervical carcinogenesis. 2003. Cancer Res. 63, 4862-4871.

22. Robertson, C. N., K. M. Roberson, G. M. Padilla, E. T. O'Brien, J. M. Cook, C. S. Kim, and R. L. Fine. 1996. Induction of apoptosis by diethylstilbestrol in hormone-insensitive prostate cancer cells. J. Natl. Cancer. Inst. 88, 908-917. 
23. Rodriguez, G. C., N. P. Nagarsheth, K. L. Lee, R. C. Bentley, D. K. Walmer, M. Cline, R. S. Whitaker, P. Isner, A. Berchuck, R. K. Dodge, and C. L. Hughes. 2002. Progestin-induced apoptosis in the Macaque ovarian epithelium: differential regulation of transforming growth factor-beta. J. Natl. Cancer Inst. 94, 50-60.

24. Roger, P., M. E. Sahla, S. Makela, J. A. Gustafsson, P. Baldet, and H. Rochefort. 2001. Decreased expression of estrogen receptor $\beta$ protein in proliferative preinvasive mammary tumors. Cancer Res. 61, 2537-2541.

25. Shai, A., A. T. Brake, C. Somoza, and P. F. Lambert. 2007. The human papillomavirus E6 oncogene dysregulates the cell cycle and contributes to cervical carcinogenesis through two independent activities. Cancer Res. 67, 1626-1635.

26. Shim, W. S., M. Conaway, S. Masamura, W. Yue, J. P. Wang, R. Kmar, and R. J. Santen. 2000. Estradiol hypersensitivity and mitogen-activated protein kinase expression in long-term estrogen deprived human breast cancer cells in vivo. Endocrinol. 141, 396-405.

27. Song, R. X., G. Mor, F. Naftolin, R. A. McPherson, J. Song, Z. Zhang, W. Yue, J. Wang, and R. J. Santen. 2001. Effect of long-term estrogen deprivation on apoptotic responses of breast cancer cells to 17beta-estradiol. J. Natl. Cancer. Inst. 93, 1714-1723.
28. Song, R. X. D. and R. J. Santen. 2003. Apoptotic action of estrogen. Apoptosis 8, 55-60.

29. Syed, V., G. Ulinski, S. C. Mok, G. K. Yiu, and S. M. Ho. 2001. Expression of gonadotropin receptor and growth responses to key reproductive hormones in normal and malignant human ovarian surface epithelial cells. Cancer Res. 61, 6768-6776.

30. Syed, V. and S. M. Ho. 2003. Progesterone-induced apoptosis in immortalized normal and malignant human ovarian surface epithelial cells involves enhanced expression of Fas1. Oncogene 22, 6993-6890.

31. Wada-Hiraike, O., O. Imamove, H. Hiraike, K. Hultenby, T. Schwend, Y. Omoto, M. Warner, and J. A. Gustafsson. 2006. Role of estrogen receptor $\beta$ in colonic epithelium. Pro. Natl. Acad Sci. 103, 2959-2964.

32. Yao, K., E. S. Lee, D. J. Bentrem, G. England, J. I. Schafer, R. M. O'Regan, and V. C. Jordan. 2000. Antitumor action of physiological estradiol on tamoxifen-stimulated breast tumors grown in athymic mice. Clin. Cancer. Res. 6, 2028-2036.

33. Zhang, C. C. and D. J. Shapiro. 2000. Activation of the p38 mitogen-activated protein kinase pathway by estrogen or by 4-hydroxytamoxifen is coupled to estrogen receptor-induced apoptosis. J. Biol. Chem 275, 479-486.

\section{초록 : 배양된 HeLa 세포에서 고농도의 에스트로겐, 프로게스테론 및 타목시펜의 세포증식 억제효과 \\ 민계식* \\ (경남과학기술대학교 제약공학과)}

이 연구는 에스트로겐, 프로게스테론 및 타목시펜의 각각 다른 농도와 처리기간에 따라 배양된 사람 난소유래 암세포주인 HeLa 세포의 증식에 미치는 영향을 MTT 분석에 의해 조사하였다. 에스트로겐은 2.5 6일의 처리기간 동안 $1 \mathrm{\mu g} / \mathrm{ml}$ 의 농도까지는 세포증식에 영향을 주지 않았지만, 더 높은 $10 \mathrm{\mu g} / \mathrm{ml}$ 의 농도에서는 처리기간의 증가 에 따라 점진적으로 현저하게 세포증식을 억제하였다. 또한 $10 \mu \mathrm{g} / \mathrm{ml}$ 농도 이상의 프로게스테론을 2.5일 동안 처리할 경우 $\mathrm{HeLa}$ 세포의 증식을 현저하게 억제하였으며, 4 일 동안 처리시에는 농도-의존성 억제효과를 나타내 었다. 그러나, 6 일 동안 더 장기간의 프로게스테론 처리는 4 일 동안의 처리기간에서 관찰된 세포증식에 대한 농도 -의존성 억제효과를 제거하였다. 그리고, 타목시펜은 $\mathrm{HeLa}$ 세포주의 증식에 대한 억제효과를 위하여 에스트로겐 보다 더 높은 농도 $(100 \mu \mathrm{g} / \mathrm{ml})$ 를 필요로 하였다. 이러한 결과는 고농도의 에스트로겐, 프로게스테론 그리고 타목 시펜이 $\mathrm{HeLa}$ 세포의 증식을 억제할 뿐만 아니라, 농도 및 처리기간 또한 세포증식에 대한 억제효과에 영향을 미칠 수 있음을 제시한다. 